\title{
EFEKTIFITAS IMUNOSTIMULAN DARI EKSTRAK ETANOL DAUN BENALU KOPI (Loranthus ferrugineus Roxb) PADA TIKUS JANTAN DENGAN METODE TITER ANTIBODI
}

\author{
Novandi Purba ${ }^{1}$, Lasma Novita Sari ${ }^{2}$, Yanna Rotua Sihombing ${ }^{3}$ \\ Institut Kesehatan Medistra Lubuk Pakam \\ e-mail: gultomvandi6196@gmail.com
}

DOI : https://doi.org/10.35451/jfm.v2i2.372

\begin{abstract}
:
The research in this paper aims to determine the effectiveness of immunostimulants from ethanol extract of coffee parasite leaves (Loranthus ferrugineus Roxb) with four variants of doses of $50 \mathrm{mg} /$ $\mathrm{kgBB}, 100 \mathrm{mg} / \mathrm{kgBB}, 200 \mathrm{mg} / \mathrm{kgBB}, 400 \mathrm{mg} / \mathrm{kgBB}$. This study used 18 male white rats with 200 gram $B B$ which were divided into 6 treatment groups. Rats were injected with $0.1 \mathrm{ml}$ SDMS $1 \%$ for 7 consecutive days intraperitoneal, then on the 7th day each blood sample was taken through veins in the tail, CMC Na $0.5 \%$ suspension, and Levamisole suspension 50mg / $\mathrm{kgBB}$ as a positive control was administered orally on the 8th day. Then blood samples were collected in a micro tube and then 1900rpm was centrifuged at a temperature of $40 \mathrm{C}$ for 10 minutes. The results of the study of ethanol extract of coffee parasite leaves proved effective as immunostimulants because they have a value close to positive control, starting from a dose of $200 \mathrm{mg} / \mathrm{kgBB}$ to $400 \mathrm{mg} / \mathrm{kgBB}$.
\end{abstract}

Keywords: Benalu coffea leaf (Loranthus ferrugineus Roxb), Flavonoid, Titer Antibodi.

\section{PENDAHULUAN}

Indonesia sebagai salah satu negara dengan keanekaragaman hayati yang sangat melimpah dan merupakan peluang bagi para peneliti khususnya yang bergerak dalam bidang eksplorasi, inventarisasi dan perkembangan obat hayati dan nabati. Untuk menjelajah dan mengeskplorasi kekayaan tersebut dalam rangka menemukan senyawa baru, spesies baru bahkan senyawa bioaktif baru diantaranya diharapkan sebagai obat bagi beberapa penyakit yang sampai saat ini belum ditemukan obatnya (Aldi,2014).

Salah satu Provinsi penghasil kopi terbesar di indonesia adalah Provinsi Aceh, yang tepatnya di daerah dataran tinggi gayo, ada berbagai jenis tanaman kopi yang tumbuh di daerah tersebut, selama ini pemanfaatan tanaman kopi secara komersial hanya terfokus pada pengolahan biji kopi sebagai minuman seduh maupun bahan tambahan makanan. Benalu kopi merupakan tumbuhan parasit pada inang kopi yang dapat merusak tanaman inangnya. Masyarakat dataran tinggi gayo memanfaatkan benalu kopi sebagai obat tradisional untuk penyembuhan berbagai penyakit seperti kanker dengan cara merebus daun benalu kopi yang sudah kering dan meminum hasil rebusan tersebut (Raja,2008).

Beberapa penelitian telah dilakukan untuk mengkaji pemanfaatan ini secara ilmiah. Artanti (2003) telah melakukan uji aktivitas antioksidan dan bioaktivitas 
terhadap ekstrak air dan ekstrak etanol daun benalu kopi (Loranthus ferrugineus Roxb.) yang tumbuh pada inang pohon nangka (Artocarpus heterophyllus). Ekstrak air ekstrak etanol daun benalu kopi (Loranthus ferrugineus Roxb.) aktif sebagai antioksidan dengan nilai IC50 23,08pg/mL dan $21,56 \mathrm{pg} / \mathrm{mL}$, untuk ekstrak etanol baik daun maupun ranting memberikan IC50 di atas $100 \mathrm{pg} / \mathrm{mL}$ (tidak aktif sebagai antioksidan terhadap DPPH). Uji aktivitas sistem imun dapat dilakukan dengan berbagai metode yaitu dengan melihat aktivitas fagositosis menggunakan metode bersihan karbon (carbon clerance), respon hipersensivitas tipe lambat, dan uji hemaglutinasi titer antibodi (Seifu,2012).

Berdasarkan pertimbangan di atas, penulis merasa penting dan perlu untuk melakukan pengujian efek imunostimulator dari ekstrak etanol dan benalu kopi (Loranthus ferrugineus Roxb.) dengan metode titer antibodi untuk melihat respon imun spesifik pada tikus jantan. Maka, diperlukan penelitian ilmiah seperti penelitian dan pengujian imunostimulator di bidang farmakologi.

\section{METODE}

Jenis penelitian ini merupakan penelitian eksperimental yang menggunakan tikus jantan sebagai hewan percobaan untuk melihat efek imunostimulator ekstrak etanol daun benalu kopi (Loranthus ferrugineus Roxb.). Penelitian ini meliputi pengumpulan dan pengolahan bahan tumbuhan, pemeriksaan karakterisasi simplisia dan ekstrak, pembuatan ekstrak etanol daun benalu kopi (Loranthus ferrugineus Roxb.), pembuatan suspensi ekstrak etanol daun benalu kopi (Loranthus ferrugineus Roxb.), dan penyiapan hewan percobaan. Metode pengujian yang digunakan adalah hipersensitivitas tipe lambat dan uji analisa data.instrumen, prosedur pengumpulan data, dan analisis data yang dipaparkan dalam bentuk paragraf.

\section{Alat}

Alat-alat yang digunakan dalam penelitian ini Alat-alat yang digunakan dalam penelitian ini adalah alat-alat gelas laboratorium, aluminium foil, neraca listrik (Vibra), seperangkat alat destilasi penetapan kadar air, rotary evaporator, blender (National), mortir dan stamfer, neraca hewan, spuit $1 \mathrm{ml}$ (Terumo), oral sonde, pletismometer air raksa, centrifuge (Dynamic), microtube, microtitration plate, micropipette (Socorex), dan kertas saring.

\section{Bahan}

Bahan-bahan yang digunakan dalam penelitian ini adalah daun benalu kopi, karboksi metil selulosa (CMC), natrium klorida $(\mathrm{NaCl})$, kalium klorida $(\mathrm{KCl})$, dinatrium hidrogen fosfat, Stimuno, (Na2HPO4), kalium dihidrogen fosfat (KH2PO4), aqua bidestilasi, heparin, etanol $96 \%$, toluen, kloroform dan air suling.

\section{Pembuatan Ekstrak}

Pembuatan ekstrak etanol dilakukan dengan metode maserasi menggunakan pelarut etanol $96 \%$. Sebanyak $5 \mathrm{~kg}$ serbuk simplisia dimasukkan kedalam wadah kaca, lalu ditambahkan pelarut etanol sampai serbuk simplisia terendam, kemudian didiamkan selama 3 hari lalu ekstrak disaring, setelah itu ekstrak dimaserasi kembali dan setelah di skrining ditemukan ekstrak mengandung flavonoid, kemudian diuapkan menggunakan rotary evaporator dengan suhu sekitar $40^{\circ} \mathrm{C}$, hasilnya diperoleh ekstrak kental (Depkes RI, 1979).

\section{Pembuatan Suspensi Ekstrak Etanol Daun benalu kopi (Loranthus ferrugineus Roxb.)}

Dalam pengujian akan digunakan 4 variasi dosis yakni dosis 50, 100, 200, dan $400 \mathrm{mg} / \mathrm{kgBB}$. Ditimbang $50 \mathrm{mg}$ Ekstrak Etanol Daun benalu kopi (Loranthus ferrugineus Roxb.). Dimasukkan ke dalam lumpang, kemudian tuang sedikit demi 
sedikit suspensi $\mathrm{CMC} \mathrm{Na} \quad 0,5 \%$ sambil digerus hingga homogen, setelah homogen dituangkan ke dalam labu tentukur $100 \mathrm{ml}$. Demikian dengan variasi dosis 100, 200, dan $400 \mathrm{mg} / \mathrm{kgBB}$.

\section{Penyiapan Kontrol, Suspensi Stimuno ${ }^{\circledR}$, inokulum bakteri dan uji titer antibody}

a. Pembuatan Suspensi CMC Na 0,5\% Pembuatan suspensi CMC Na 0,5\% dilakukan dengan cara sebagai berikut: sebanyak 0,5 gram CMC Na ditaburkan ke dalam lumpang yang berisi air panas sebanyak $20 \mathrm{ml}$. Didiamkan selama 15 menit, kemudian digerus hingga diperoleh massa yang transparan, diencerkan dengan sedikit air, kemudian dituang ke dalam labu tentukur $100 \mathrm{ml}$, ditambah air suling sampai batas tanda.

b. Penyiapan suspensi levamisole

Pengambilan sampel tablet levamisole yaitu dengan cara timbang setara dan diserbukhaluskan tidak kurang dari 10 tablet. Serbuk yang telah dihaluskan tersebut kemudian ditimbang setara dengan lebih kurang $50 \mathrm{mg}$ levamisole. Pembuatan suspensi levamisole dilakukan dengan cara sebagai berikut: ditimbang serbuk levamisole dan dimasukan kedalam lumpang. Digerus serbuk kemudian ditambahkan suspensi CMC Na 0,5\% secukupnya. Digerus hingga homogen dan dituangkan kedalam labu tentukur 25 $\mathrm{ml}$, dan kemudian ditambahkan suspensi CMC Na 0,5\% sampai batas tanda.

c. Penyiapan Phosphate Buffered Saline (PBS)

Pembuatan PBS dilakukan dengan cara sebagai berikut: sebanyak $8 \mathrm{~g} \mathrm{NaCl}$, $0,2 \mathrm{~g} \mathrm{KCl}, 1,44 \mathrm{~g} \mathrm{Na}$ HPO4, 0,24 g $\mathrm{KH} 2 \mathrm{PO} 4$, dilarutkan dalam $800 \mathrm{ml}$ aqua bidestilasi, kemudian dicek $\mathrm{pH}$ dengan indikator $\mathrm{pH}$ hingga $\mathrm{pH} \pm 7$ dan dapat disesuaikan dengan penambahan $\mathrm{HCl}$ atau $\mathrm{NaOH}$, tambahkan aqua bidestilasi hingga $1 \mathrm{~L}$ (Rahmi, 2011).

d. Uji Titer Antibodi

Tiap kelompok hewan percobaan diinjeksikan dengan 0,1 ml SDMS 1\% dalam PBS sebagai antigen secara intraperitoneal pada hari ke-0. Perlakuan dimulai dari hari ke-0 dan diberikan satu kali sehari selama 7 hari. Pada hari ke-7, sampel darah masing-masing tikus diambil melalui pembuluh darah vena di bagian ekor. Caranya dengan modifikasi yaitu bagian ujung dari ekor tikus disayat dengan menggunakan silet kemudian darah yang keluar disedot dengan menggunakan spuit $1 \mathrm{ml}$, selanjutnya sampel darah dikumpulkan dalam tabung mikro (microtube), kemudian dilakukan pemusingan $1900 \mathrm{rpm}$ dengan alat sentrifugasi pada suhu $40 \mathrm{C}$ selama 10 menit dan diambil serumnya. Nilai titer antibodi ditentukan dengan teknik hemaglutinasi. $25 \mu \mathrm{l}$ serum diteteskan ke dalam sumur microtitration plate 96 lubang, ditambahkan PBS dan SDMS dengan volume yang sama, dan diencerkan dua kali lipat $(1: 2 ; 1: 4$; $1: 8 ; 1: 16 ; 1: 32 ; 1: 64 ; 1: 128 ; 1: 256$; $1: 512 ; \quad 1: 1024 ; 1: 2048 ; 1: 4096)$ kemudian diinkubasi pada suhu $370 \mathrm{C}$ selama 1 jam dan diamati hemaglutinasi secara visual. Nilai titer antibodi ditentukan berdasarkan pengenceran terakhir di mana antibodi masih terdeteksi melalui hemaglutinasi yang terlihat secara visual. Nilai titer antibodi tersebut selanjutnya ditransformasikan dengan [2log(titer)+1] (Marbun, 2018).

\section{Hasil Dan Pembahasan}

Pada penelitian ini, pengujian efek imunomodulator ekstrak etanol daun benalu kopi (Loranthus ferrugineus Roxb.)/ EEBK dilakukan dengan metode respon 
untuk mengetahui pengaruh daun benalu kopi (Loranthus ferrugineus Roxb.) terhadap respon imun spesifik humoral.

Pengujian dilakukan dengan cara menginduksi sel imun tikus dengan sel darah merah sapi (SDMS) secara intraperitonium pada hari ke-0. Pemberian SDMS $1 \%$ yang digunakan sebagai antigen pada tikus dimaksudkan untuk merangsang pembentukan antibodi spesifik. Injeksi ini dilakukan secara intraperitonium agar didapat reaksi respon imun yang cepat dan maksimum. Pada pembuatan SDMS $1 \%$ digunakan PBS (Phosphate buffer saline) Buffered Saline) sebagai larutan pencuci dan larutan pengencer. Pencucian SDMS bertujuan untuk memperoleh sel darah merah sapi yang murni artinya tidak dicemari oleh protein serum (Puri, 1993).

Pengukuran nilai titer antibodi dilakukan pada hari ke-7 dengan menggunakan metode hemaglutinasi. Hemaglutinasi adalah ikatan antara sel darah merah sebagai antigen dengan antibodi sehingga menimbulkan suatu gumpalan yang dapat dilihat. Pada lingkungan dengan $\mathrm{pH}$ netral, sel darah merah bermuatan negatif sehingga akan terjadi aksi tolak menolak antar sel. Oleh karena itu sel darah merah yang digunakan disuspensikan dalam larutan penyangga dengan $\mathrm{Ph} \pm 7$ (PBS) untuk menjaga agar sel darah merah tetap dalam kondisi $\mathrm{pH}$ netral, sehingga tetap bermuatan negatif. Hemaglutinasi terbentuk karena adanya ikatan silang antara sel darah merah dengan antibodi.

Antibodi yang mempunyai kemampuan lebih besar untuk berikatan dengan sel darah merah adalah IgM. IgM mempunyai ukuran yang besar dan valensi yang tinggi, sehingga dapat melawan rintangan elektrik dan membentuk ikatan silang dengan sel darah merah sehingga menyebabkan aglutinasi. Antibodi lainnya seperti IgG mempunyai ukuran dan valensi yang lebih kecil, sehingga kemampuannya melawan rintangan elektrik lebih lemah dibandingkan dengan IgM (Puri,et al.,1993). Data nilai titer antibodi dapat dilihat pada Tabel 1 di bawah ini.

Tabel 1. Data nilai titer antibodi

\begin{tabular}{|c|c|c|c|}
\hline \multirow{2}{*}{ No. } & \multirow{2}{*}{ Perlakuan } & \multicolumn{2}{|c|}{ Nilai titer antibody } \\
\hline & & $\begin{array}{c}\text { Titer } \\
\text { antibody }\end{array}$ & $\begin{array}{c}{[2(\log } \\
\text { titer })+1]\end{array}$ \\
\hline 1 & CMC Na $0,5 \%$ & 16 & 3,40 \\
\hline 2 & Suspensi Levamisole 25 mg/kgBB & 256 & 5,81 \\
\hline 3 & Suspensi EEBK 50 mg/kgBB & 32 & 4,01 \\
\hline 4 & Suspensi EEBK 100 mg/kgBB & 57,6 & 4,49 \\
\hline 5 & Suspensi EEBK 200 mg/kgBB & 102,4 & 5,02 \\
\hline 6 & Suspensi EEBK 400 mg/kgBB & 128 & 5,21 \\
\hline
\end{tabular}

Hemaglutinasi terbentuk karena adanya ikatan silang antara sel darah merah dengan antibodi. Antibodi yang mempunyai kemampuan lebih besar untuk berikatan dengan sel darah merah adalah IgM. IgM mempunyai ukuran yang besar dan valensi yang tinggi, sehingga dapat melawan rintangan elektrik dan membentuk ikatan silang dengan sel darah merah sehingga menyebabkan terjadinya aglutinasi. Antibodi lainnya seperti IgG mempunyai ukuran dan valensi yang lebih kecil, sehingga kemampuannya melawan rintangan elektrik lebih lemah dibandingkan dengan IgM. Data nilai titer antibodi dapat dilihat pada Gambar 1 di bawah ini. 
Nilai titer antibodi

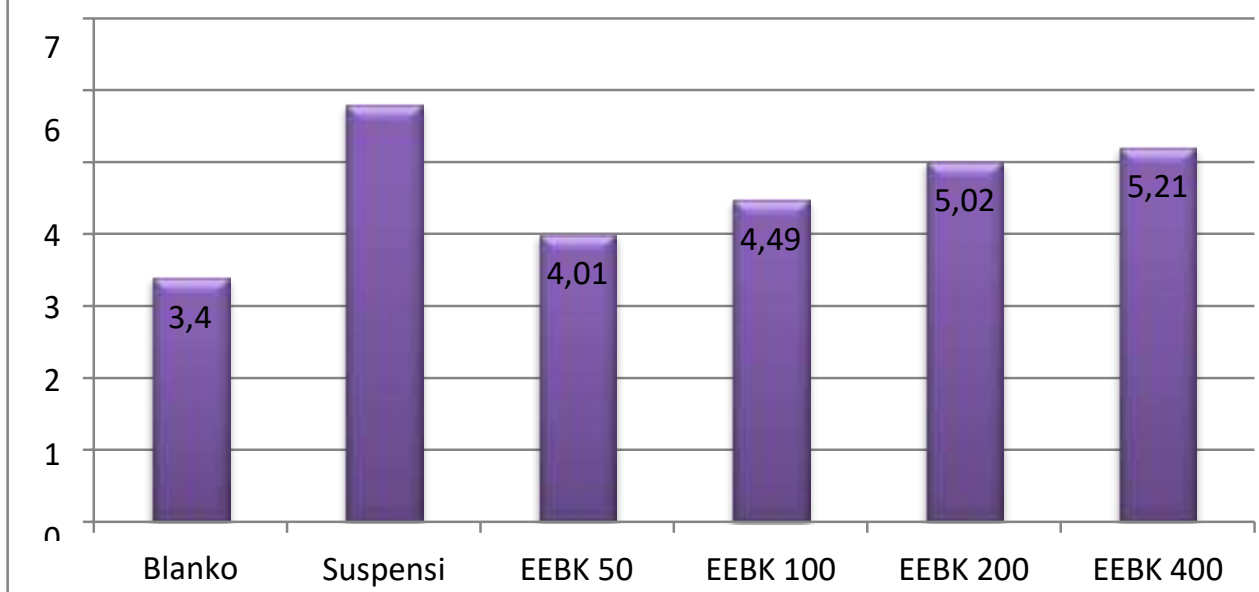

Gambar 1. EEBK $50,100,200,400$ mg/kgBB

\section{SIMPULAN DAN SARAN}

\section{Simpulan}

Peningkatan dosis ekstrak etanol daun benalu kopi (Loranthus ferrugineus Roxb.) dapat meningkatkan nilai titer antibodi pada tikus jantan. Peningkatan dosis terbaik ekstrak etanol daun benalu kopi (Loranthus ferrugineus Roxb.) dapat

\section{DAFTAR PUSTAKA}

Buku:

Harborne, J.B. (1998). Phytochemical Methods. Third edition. United of Kingdom: University of Reading. Halaman 214.

\section{Jurnal:}

Artanti, N., Jamilah, dan Hartati, S.(2003). Laporan Teknis Sub Tolok Ukur Pengembangan Senyawa Potensial antikanker dari Taxus sumatrana dan Benalu, Puslit Kimia LIPI, Serpong.

Aldi, Rasyadi, Y., dan Handayani, D. (2014).Aktivitas Imunomodulator dari Ekstrak Etanol Meniran meningkatkan respon imun spesifik pada tikus jantan.

\section{Saran}

Untuk peneliti selanjutnya disarankan perlu melakukan penelitian lebih lanjut untuk melihat apakah Ekstrak Etanol daun benalu kopi (Loranthus ferrugineus Roxb.) dapat diformulasikan sebagai sediaan farmasi (Herbal).

(Phyllanthus niruri Linn.) terhadap Ayam Broiler. Jurnal Sains Farmasi dan Klinis Fakultas Farmasi. 1(1): 20-26.

Marbun, R. (2018). Test Of Immunomodulatory Effects From Ethanol Extract Herbs Binara (Artemisia Vulgaris L.) In Male Rats. Asian Journal Pharmaceutical and Clinical research. 11(1):246.

Marbun, R., Suwarso, E. and Yuandani, Y. (2018) "IMMUNOMODULATORY EFFECTS OF ETHANOL EXTRACT ARTEMISIA VULGARIS L. IN MALE RATS", Asian Journal of 
Pharmaceutical and Clinical Research, 11(13), pp. 245-247. doi:10.22159/ajpcr.2018.v11s1.2 6619.

Baratawidjaja, K. (2012). Imunologi Dasar. Edisi ke IX. Yogyakarta: Balai Penerbit Fakultas Kedokteran Universitas Indonesia. Halaman 418.

Puri, S., dan Bagchi, K. (1993). Free Radical and Antioxidant in Health and Disease. Eastern Mediterranean Health Journal. 4(2): 1979-249.

Raja L.L.(2008).Uji Efek Ekstrak Etanol Daun Benalu Kopi (Swietenia mahagoni Jacq) terhadap Penurunan Kadar Gula Darah Tikus Putih, Skripsi, Fakultas Farmasi USU.

Rahmi, T.F. (2011). Gambaran Higiene dan Sanitasi Penyelenggaraan Makanan PT Nuansa Boga Sehatama Tahun 2011. Skripsi. Fakultas Farmasi. Universitas Islam Negeri Syarif Hidayatullah: Jakarta. Halaman 37-39.

Seifu,D., Assefa, F. \& Abay, S.M. (2012). Medicinal plants as antioxidant agent: understanding their mechanism of action and therapeutic efficacy. In Capasso,(ed). Medicinal Plants as Antioxidant Agents: Understanding Their Mechanism of Action and Therapeutic Efficacy. Pp. 97 - 145

Oktianti, Dian, Nova,H.F., dan Agnes,B. (2015). Uji Aktivitas Imunostimulan Infusa Daun Cermai (Phyllanthus acidus L. Skeells) Pada Tikus Jantan Galur Sprague Dawley yang Diinduksi Sel Darah Merah Domba. Jurnal
Farmasi dan Obat Alam.2(3): 2834.

\section{Peraturan dan Undang-undang:}

Depkes RI. (1979). MateriaMedika Indonesia.Jilid III. Jakarta: Departemen Kesehatan RI. Halaman 33, 167-170. 